\title{
ВИКОРИСТАННЯ ТЕХНОЛОГІЙ КООПЕРАТИВНОГО НАВЧАННЯ У ПРОФЕСІЙНІЙ ПІДГОТОВЦІ МЕДИЧНИХ СЕСТЕР АВСТРІЇ
}

\author{
H. B. Palasyuk, B. M. Palasyuk, N. M. Yarema \\ I. Horbachevsky Ternopil State Medical University
APPLICATION OF COOPERATIVE LEARNING TECHNOLOGIES IN THE PROFESSIONAL TRAINING OF NURSES IN AUSTRIA

\begin{abstract}
Мета роботи - аналіз використання технологій кооперативного навчання у професійній підготовці австрійських медичних сестер.

Основна частина. Кооперативне навчання широко використовується на різних рівнях австрійської освіти. Перевагами кооперативного навчання $€$ підвищення академічних результатів студентів; розвиток здатності критично мислити і нестереотипно сприймати інших людей; позитивний психологічний клімат у групі; прагнення студентів до співробітництва та конструктивної соціалізації; наявність емпатійної реакції, взаємопідтримки, симпатії та дружніх стосунків у колективі; позитивне ставлення студентів до навчання, викладачів та навчального закладу; особистісне зростання; високий рівень самоповаги та психічного здоров’я, яке виявляється в емоційній врівноваженості, усвідомленні особистісної індивідуальності, прояві довіри, оптимістичному сприйнятті світу й оточення. Педагоги розробили п'ять базових принципів кооперативного навчання, які відрізняють його від традиційних групових форм роботи на занятті: позитивної взаємозалежності; індивідуальної відповідальності; тісної міжособистісної взаємодії; здійснення успішної комунікації; груповий аналіз результатів, який проводиться з метою оцінки успішності досягнення спільної мети навчальної діяльності та продуктивності кооперації.

Важливе значення застосування технології кооперативного навчання у професійній підготовці медичних сестер полягає у тому, що, на відміну від традиційних форм і методів навчальної діяльності, кооперативне навчання допомагає досягнути не лише когнітивної, а також мотиваційної та емоційної мети, розвиває здатність взяти на себе відповідальність за власне навчання, тобто вміння самостійно організувати навчальний процес. При цьому важливу роль відіграє здатність до саморефлексії, тобто вміння самостійно оцінювати власні результати та досягнення.

Висновок. Використання технологій кооперативного навчання дозволяє не тільки вдосконалити практичні навички, а й розвинути клінічне мислення майбутніх фахівців з медсестринства, адаптувати їх до нестандартних ситуацій, відпрацювати всі необхідні етапи діяльності майбутньої медсестри.
\end{abstract}

Ключові слова: професійна підготовка; медична сестра; Австрія; кооперативне навчання.

The aim of the work - to analyze the use of cooperative training technology in the training of Austrian nurses.

The main body. Cooperative training is widely used at different levels of Austrian education. The benefits of cooperative learning are to increase academic outcomes of students; development of the ability to think critically and not stereotypically perceive other people; positive psychological climate in the group; the aspiration of students for cooperation and constructive socialization; presence of empathy reaction, mutual support, sympathy and friendly relations in the team; positive attitude towards students, teachers and educational institutions; personal growth; a high level of self-esteem and mental health that manifests itself in emotional balance, awareness of personal identity, a manifestation of trust, an optimistic perception of the world and the environment. Teachers have developed five basic principles of cooperative learning that distinguish it from the traditional group forms of work in the class: positive interdependence; individual responsibility; close interpersonal interaction; successful communication; a group analysis of the results conducted to assess the success of the overall goal of learning activities and the productivity of co-operation. The importance of the use of cooperative educational training in the training of nurses is that, unlike traditional forms and methods of educational activity, co-operative learning helps to achieve not only cognitive, but also motivational and emotional goals, develops the ability to take responsibility for their own training, that is, the ability to independently organize the learning process. At the same time, an important role is played by the ability to self-reflection, that is, the ability to independently evaluate own results and achievements.

Conclusion. The use of co-operative learning technologies can not only improve practical skills, but also develop the clinical thinking of future nursing professionals, adapt them to non-standard situations, and work out all the necessary stages of the future nurse's activities.

Key words: professional training; nurse; Austria; cooperative learning.

(ㄷ Г. Б. Паласюк, Б. М. Паласюк, Н. М. Ярема 
Вступ. В умовах докорінних змін у вітчизняній системі освіти та інтеграції України у європейський освітній простір особлива увага приділяється вивченню та впровадженню в навчальний процес вищої школи України сучасних методів та форм навчання, які успішно використовуються у професійній підготовці фахівців різних європейських країн. У зарубіжному науково-практичному досвіді останнім часом спостерігається тенденція переходу від індивідуалістичної форми навчальної взаємодії до кооперативного навчання, яке сприяє розвиткові вміння ефективно взаємодіяти у групі і водночас посилює автономність студентів [1].

Професія медсестри в австрійському суспільстві має високий соціальний рейтинг, що забезпечується університетською освітою, яскраво виражену особистісно-гуманістичну спрямованість, є самостійною професією, де медсестра - незалежний спеціаліст системи охорони здоров'я. Про престижність і значимість сестринської справи в Австрії свідчать автономність, високий соціальний статус, можливість постійного навчання і кар'єрного росту фахівців з медсестринства.

Професійна підготовка австрійської медичної сестри сьогодні значно ускладнюється за своїми завданнями. У сучасних умовах вона несе велику відповідальність у діагностично-лікувальному процесі. У коло ії функціональних обов'язків входить прийняття абсолютно всіх рішень щодо організації висококваліфікованого догляду за хворим. Розширення кола функціональних обов'язків і підвищення рівня складності професійної діяльності фахівців з догляду за хворими в сучасних умовах вимагає постійного пошуку нових форм та методів навчання, які сприяли б покращенню якості їх підготовки і в перспективі підвищенню якості медичних послуг.

Дослідженню проблеми використання технологій кооперативного навчання присвятили свої дослідження вітчизняні педагоги М. В. Байда, Н. В. Гагіна, Т. С. Кошманова, І. В. Михайлова, К. Ф. Нор, Л. В. Пироженко, О. І. Пометун, О. Ю. Пришляк, Г. О. Сиротенко, В. Ю. Стрельніков та інші. Різні аспекти кооперативного навчання висвітлені у наукових дослідженнях і практичних розробках зарубіжних вчених - Е. Аронсона, Д. Джонсона, Р. Джонсона, С. Кагана, Е. Коен, Н. Медден, Р. Славіна, Е. Холубек, Ш. Шарана та інших. Аналіз зарубіжних наукових досліджень показує, що кооперативне навчання широко використовується у педагогічний практиці США, країн Європи, зокрема Австрії.
Мета роботи - аналіз використання технологій кооперативного навчання у професійній підготовці австрійських медичних сестер.

Основна частина. Згідно 3 розпорядженням Федерального міністерства охорони здоров'я, навчальна діяльність у медсестринських школах Австрії повинна базуватись на таких дидактичних принципах, як:

- принцип плюралізму методів і засобів навчання і їх раціонального застосування передбачає застосування методів навчання, які забезпечують ефективність пізнавальної діяльності студентів. При виборі методів навчання доцільно надавати перевагу тим, які унеможливлюють догматичне сприйняття навчального матеріалу, а сприяють стимуляції мисленнєвої діяльності студентів, розвиткові клінічного мислення і навиків розв'язання складних проблем;

- на всіх заняттях рекомендується актуалізувати так зване “суспільне навчання”, яке дозволяє розвинути комунікативні навички, самостійність і толерантність, а також здатність застосовувати наявні допоміжні засоби і знаходити нові для розв'язання проблемних ситуацій.

Технології кооперативного навчання сприяють впровадженню цих принципів у навчальну діяльність при підготовці медичних сестер Австрії, дозволяють не тільки вдосконалити практичні навички, а й розвинути клінічне мислення майбутніх фахівців 3 медсестринства, адаптувати їх до нестандартних ситуацій, відпрацювати всі необхідні етапи діяльності майбутньої медсестри. Кооперативне навчання широко використовується на різних рівнях австрійської освіти.

Перевагами кооперативного навчання, на думку науковців [2], є підвищення академічних результатів студентів; розвиток здатності критично мислити і нестереотипно сприймати інших людей; позитивний психологічний клімат у групі; прагнення студентів до співробітництва та конструктивної соціалізації; наявність емпатійної реакції, взаємопідтримки, симпатії та дружніх стосунків у колективі; позитивне ставлення студентів до навчання, викладачів та навчального закладу; особистісне зростання; високий рівень самоповаги та психічного здоров'я, яке виявляється в емоційній врівноваженості, усвідомленні особистісної індивідуальності, прояві довіри, оптимістичному сприйнятті світу й оточення.

Окремої уваги заслуговує наукове дослідження австрійської вченої Даніели Янкер, у якому про- 
аналізовано використання технологій кооперативного навчання в умовах австрійської вищої освіти і у професійній підготовці медичних сестер зокрема. Даніела Янкер трактує кооперативне навчання як вид навчання, яке дає можливість гетерогенній малій групі студентів шляхом кооперативної взаємодії досягнути спільної навчальної мети [3]. На думку авторки, застосування технологій кооперативного навчання у професійній підготовці медичних сестер у медсестринських школах сприяє формуванню у студентів навиків групової роботи, необхідних у їх майбутній професійній діяльності.

Австрійські вчені [4] наголошують, що кооперативне навчання завжди відбувається в групах, але не кожна групова робота відповідає принципам навчальної кооперації. 3 метою диференціації навчальної кооперації від інших форм групової роботи відомі педагоги брати Давід і Рогер Джонсони розробили п’ ять базових принципів кооперативного навчання, які відрізняють його від традиційних групових форм роботи на занятті, метою яких є не підвищення індивідуального рівня навчальних досягнень студентів, а лише результат.

Перший принцип співпраці в кооперативній групі базується на позитивній взаємозалежності. Німецький вчений Ф. Борш [5] вважає, що цей принцип $є$ основоположним всякої кооперації і описує його на прикладі альпіністів, зв' язаних одним канатом кожен з них зійде на вершину лише тоді, коли це зможуть зробити усі. Кожен член групи повинен зробити посильний внесок у спільну справу, а результат діяльності кожного залежить від успішності виконання завдання іншими членами групи. Отже, позитивна взаємозалежність сприяє виникненню у студентів стимулу до навчання, спонукає до взаємодопомоги, активної співпраці, взаємної відповідальності, зумовлює необхідність взаємоконтролю, забезпечує об’ єднання зусиль студентів для досягнення спільної мети.

Інший дослідник, М. Гассельгорн, [6] стверджує, що для досягнення позитивної взаємозалежності в групі необхідно так визначити спільну мету і таким чином сформулювати завдання, щоб їх можна було вирішити лише шляхом кооперації. Цього можна досягнути за допомогою спеціального розподілу навчального матеріалу (наприклад, коли студент має тільки частину матеріалу, необхідного для виконання спільного завдання); призначення ролей (керівник групи, експерт, доповідач, спостерігач та ін.); підсумовування балів, отриманих членами групи при оцінюванні; призначення колективної винагороди. Автор наголошує, що викладач повинен сформулювати завдання таким чином, щоб їх можна було вирішити при умові безпосередньої індивідуальної діяльності кожного члена групи.

3 принципом позитивної взаємозалежності тісно пов’язаний другий принцип співпраці у кооперативній групі - принцип індивідуальної відповідальності. Викладач повинен контролювати, щоб усі студенти активно працювали, не допускати можливості виконання завдань одними студентами замість інших, виявляти студентів, які потребують допомоги. 3 цією метою викладач за допомогою індивідуальних тестів, опитування чи інших видів контролю перевіряє і оцінює не тільки кінцевий результат діяльності всієї групи, а й роботу кожного студента. При цьому оцінка за виконання індивідуальної роботи вища, якщо всі студенти успішно виконали завдання і досягли поставленої мети.

Д. Джонсон і Р. Джонсон [2] рекомендують для кооперативної роботи обирати невеликі групи. Вчений вважає, що чим менша група, тим більша індивідуальна відповідальність і тим легше викладачу тримати у полі зору всіх студентів групи i коректувати їх роботу. Інший вчений, С. Каган, вважає найбільш ефективною для кооперативного навчання групу з чотирьох студентів, яку при необхідності можна поділити на дві пари.

До третього принципу навчальної кооперації вчені відносять тісну міжособистісну взаємодію. За Д. Джонсоном і Р. Джонсоном [2], студенти повинні мати змогу підтримувати один одного, підбадьорювати, хвалити за успіхи, стимулювати навчальну активність один одного, когнітивно і емпатійно реагувати на поведінку партнерів. Вчені [6] підкреслюють, що при цьому немаловажне значення має розташування студентів групи. Вони рекомендують, щоб студенти розташовувались під час роботи у позиції “обличчя до обличчя”. У цьому випадку лідер групи виконує функції, які при традиційних формах заняття, як правило, виконує викладач. Інші автори [7] акцентують увагу на необхідності дотримання часових меж при виконанні завдання. Чітко регламентуючи час виконання завдань, викладач змушує студентів зосередитися і стимулює їх не витрачати час на другорядні справи.

Четвертий принцип кооперативного навчання полягає у тому, що, на відміну від традиційної роботи у групах, всі члени групи повинні мати певні соціальні навички для здійснення успішної комунікації. Міжособистісна взаємодія в групі часто супроводжується конфліктом ідей, думок, підхо- 
дів, а вміння припинити суперечку, перевести ії у конструктивну дискусію, створити атмосферу толерантності і довіри сприяє глибшому розумінню і запам'ятовуванню навчального матеріалу, забезпечує навчальну мотивацію. Студенти набувають досвіду конструктивного розв’язання конфліктів на основі діалогової комунікації, вчаться створювати довірливу атмосферу, переконувати партнерів й аргументувати свою точку зору.

Навики міжособистісної кооперації цілеспрямовано формуються викладачем у спеціально створених навчальних ситуаціях. С. Каган виділяє чотири рівні складності формування кооперативних навичок. Для згуртування групи і встановлення норм поведінки необхідні навички першого рівня - називати один одного по імені, не перебивати, уважно слухати партнерів тощо. Навички другого рівня, на думку вченого, необхідні для організації та забезпечення ефективної групової роботи. До таких навичок він відносить навички виражати підтримку, висловлювати прохання про допомогу, заохочувати до роботи тощо. Навички підсумовувати прочитане, виділяти основне, пов'язувати матеріал із раніше вивченим відносяться до третього рівня і, як вважає С. Каган, забезпечують ментальну співпрацю для кращого засвоєння навчального матеріалу. Навички четвертого, найвищого рівня - критикувати ідею, а не партнера, аргументувати свою думку, переконувати, робити висновки, знаходити альтернативу тощо сприяють глибокому розумінню навчального матеріалу, стимулюють творчий пощук раціональних рішень.

Останнім принципом навчальної кооперації є груповий аналіз результатів, який проводиться 3 метою оцінки успішності досягнення спільної мети навчальної діяльності та продуктивності кооперації. Під час рефлексії, яка здійснюється у формі обговорення в групі індивідуальних та колективних труднощів і досягнень, студенти оцінюють,

\section{Список літератури}

1. Михайлова І. В. Кооперативне навчання як вид автономного навчання у вищій школі / I. В. Михайлова // Гуманітарний вісник ДВНЗ “Переяслав-Хмельницький державний педагогічний університет імені Григорія Сковороди”. - 2014. - Дод. 1 до вип. 5, т. 1 : Тематичний випуск “Вища освіта України у контексті інтеграції до європейського освітнього простору”. - С. 249-257.

2. Johnson D. W. Learning together and alone: Cooperative, competitive, and individualistic learning / D. W. Johnson, R. T. Johnson. - Boston, 1984. - 97 p. наскільки ефективно вони взаємодіють, які моделі поведінки є корисними у процесі спільної роботи і що необхідно змінити для забезпечення злагодженої результативної роботи групи, приймають рішення щодо подальшого вдосконалення співпраці.

Власне представлена модель відрізняє кооперативне навчання від традиційних групових форм роботи на занятті, метою яких є не підвищення індивідуального рівня навчальних досягнень студентів, а лише результат.

Маючи високий рівень теоретичної підготовки, достатньою мірою володіючи необхідними професійними навичками та маніпуляційними техніками, майбутні медичні сестри не вміють застосувати отримані знання й уміння у нестандартних, нетипових ситуаціях. Оптимальною умовою подолання визначених проблем є спрямування навчання не на засвоєння значної кількості інформації з подальшим її відтворенням, а на активний пошук та критичний аналіз необхідного матеріалу, творчого підходу до розв’язання проблем. Як наслідок отримання суб'єктивно нових знань, які, за умови практичної діяльності, легко трансформуються у професійні уміння.

Висновки. Отож, важливе значення застосування технології кооперативного навчання у професійній підготовці медичних сестер полягає у тому, що, на відміну від традиційних форм і методів навчальної діяльності, кооперативне навчання допомагає досягнути не лише когнітивної, а також мотиваційної та емоційної мети, розвиває здатність взяти на себе відповідальність за власне навчання, тобто вміння самостійно організувати навчальний процес. При цьому важливу роль відіграє здатність до саморефлексії, тобто вміння самостійно оцінювати власні результати й досягнення.

Перспективою нашого дослідження є використання ефективних методів та прийомів навчальної кооперації та їх апробація у навчальному процесі.

3. Kagan S. Kagan Cooperative learning / S. Kagan, M. Kagan. - San Klemente, CA : Kagan Publishing, 2000. - 208 p.

4. Janker D. Kooperatives Lernen im Ausbildungsbereich der Gesundheits- und Krankenpflege und die Umsetzung im Gesundheits- und Krankenpflegeunterricht des 1. Ausbildungsjahres / Daniela Janker. - Graz, 2014. - 97 p.

5. Weidner M. Kooperatives Lernen im Unterricht / M. Weidner. - Kallmeyer : Klett, 2006. - 192 p.

6. Borsch F. Kooperatives Lehren und Lernen im schulischen Unterricht / F. Borsch. - Stuttgart, 2010. - 63 p. 
7. Hasselhorn M. Pädagogische Psychologie / M. Hasselhorn, A. Gold. - Stuttgart, 2013. - 537 p.

\section{References}

1. Mykhailova, I.V. (2014). Kooperatyvne navchannia yak vyd avtonomnoho navchannia u vyshchii shkoli [Cooperative learning as a type of autonomous education in high school]. Humanitarnyi visnyk DVNZ «PereiaslavKhmelnytskyi derzhavnyi pedahohichnyi universytet imeni Hryhoriia Skovorody». Tematychnyi vypusk «Vyshcha osvita Ukrainy u konteksti intehratsii do yevropeyskoho osvitnoho prostoru - Humanitarian Journal of the State Higher Educational Institution "Pereiaslav-Khmelnytskyi State Pedagogical University named after Hryhorii Skovoroda”. Thematic issue "Higher Education of Ukraine in the Context of Integration into the European Educational Space, 1 (1), 5, 249-257 [in Ukrainian].

2. Johnson, D.W., \& Johnson, R.T. (1984). Learning together and alone: Cooperative, competitive, and individualistic learning. Boston.
8. Green N. Kooperatives Lernen im Unterricht und im Kolegium. Das Trainingsbuch / N. Green, K. Green. - Kallmeyer : Klett, 2005. - 140 p.

3. Kagan, S., \& Kagan, M. (2000). Kagan Cooperative learning. San Klemente, CA: Kagan Publishing.

4. Janker, D. (2014). Kooperatives Lernen im Ausbildungsbereich der Gesundheits- und Krankenpflege und die Umsetzung im Gesundheits- und Krankenpflegeunterricht des 1. Ausbildungsjahres. Graz.

5. Weidner, M. (2006). Kooperatives Lernen im Unterricht. Kallmeyer: Klett.

6. Borsch, F. (2010). Kooperatives Lehren und Lernen im schulischen Unterricht. Stuttgart.

7. Hasselhorn, M., \& Gold, A. (2013). Pädagogische Psychologie. Stuttgart.

8. Green, N., \& Green, K. (2005). Kooperatives Lernen im Unterricht und im Kolegium. Das Trainingsbuch. Kallmeyer: Klett. 